\title{
Multiphase Flow Modeling - Validation and Application CRADA MC94-019, Final Report
}

\author{
Madhava Syamlal \\ Philip A. Nicoletti
}

August 31, 1995

U.S. Department of Energy

Federal Energy Technology Center

P.O. Box 880

3610 Collins Ferry Road

Morgantown, WV 26507-0880

and

Fluent, Inc.

Centerra Resource Park

10 Cavvendish Court

Lebanon, NH 03766-1442 


\section{DISCLAIMER}

This report was prepared as an account of work sponsored by an agency of the United States Government. Neither the United States Government nor any agency thereof, nor any of their employees, make any warranty, express or implied, or assumes any legal liability or responsibility for the accuracy, completeness, or usefulness of any information, apparatus, product, or process disclosed, or represents that its use would not infringe privately owned rights. Reference herein to any specific commercial product, process, or service by trade name, trademark, manufacturer, or otherwise does not necessarily constitute or imply its endorsement, recommendation, or favoring by the United States Government or any agency thereof. The views and opinions of authors expressed herein do not necessarily state or reflect those of the United States Government or any agency thereof. 


\section{DISCLAIMER}

Portions of this document may be illegible in electronic image products. Images are produced from the best available original document. 


\section{Disclaimer}

This report was prepared as an account of work sponsored by an agency of the United States Government. Neither the United States Government nor any agency thereof, nor any of their employees, makes any warranty, express or implied, or assumes any legal liability or responsibility for the accuracy, completeness, or usefulness of any information, apparatus, product, or process disclosed, or represents that its use would not infringe privately owned rights. Reference herein to any specific commercial product, process, or service by trade name, trademark, manufacturer, or otherwise does not necessarily constitute or imply its endorsement, recommendation, or favoring by the United States Government or any agency thereof. The views and opinions of authors expressed herein do not necessarily state or reflect those of the United States Government or any agency thereof. 


\title{
DOEFETC Aी OSI \\ CRADA 94-019 \\ Final Report
}

Fluent Users' Group Meeting, Burlington, Vermont, August 29-31, 1995

\author{
Multiphase Flow Modeling -- Validation and Application \\ Madhava Syamlal and Philip A. Nicoletti \\ EG\&G, T.S.W.V., Inc., Morgantown, WV
}

For the development and validation of the multiphase flow modeling capability in Fluent, a cooperative research and development agreement (CRADA) is in effect between Morgantown Energy .Technology Center (METC) and Fluent Inc. To validate the Fluent multiphase model, several simulations were conducted at METC and the results were compared with the results of MFIX, a multiphase flow code developed at METC, and with experimental data. The results of these validation studies will be presented. In addition, the application of multiphase flow modeling will be illustrated by presenting the results of simulations of a filter backflushing and a fluidized bed coal gasifier. These simulations were conducted only with MFIX, since certain features needed in these simulations will be available only in the next release of Fluent.

Fluent and MFIX were used to simulate the injection of a solids slurry into a tank. The solids settle out and slowly fill the tank. The solids build-up in the tank predicted by Fluent and MFIX were compared and found to be in excellent agreement. A bubbling fluidized bed experiment (Rowe and Partridge 1965) was simulated and the predicted bubble rise velocity was compared with experimental data. A turbulent gas-solids jet experiment (Tsuji et al. 1988) was simulated, and the steady-state gas and solids velocity profiles were compared with experimental data.

An example application is the simulation of a filter back-flushing. In this operation a high pressure pulse is used to dislodge the cake on a ceramic filter. To determine the fate of the dislodged filter cake, three size fractions in the filter cake were described in the simulation. The simulation results show the motion of the three size fractions toward a collection hopper at the bottom of the filter vessel. Such results can be used for designing the baffles in the filter vessel to prevent the reentrainment of the particles from the filter cake.

Another example is the simulation of a fluidized bed gasifier, which produces fuel gas by reacting coal with air and steam. In this simulation the gasifier is described in terms of three phases (gas, coal, and char), eight gas species, four species in each of the solids phases, and thirteen gas phase and gas-solids reactions. The simulation results provide information on the nature of the combustion zone, the solids recirculation rate, the maximum solids temperature, and the location where coal devolatilization is completed. The results were used to identify regions of the gasifier where the particles have a proclivity to agglomerate.

Rowe, P.N., and B.A. Partridge, "X-Ray study of bubbles in fluidised beds," Trans. Inst. Chem. Eng., 43, T157-T175 (1965).

Tsuji, Y., Y. Morikawa, T. Tanaka, K. Karimine, and S. Nishida, "Measurement of an axisymmetric jet laden with coarse particles," Int. J. Multiphase Flow, 14, 565-574 (1988). 